\title{
The Effects Of High Scientific Literacy, Self-Efficacy, And Achievement Motivation On Teachers' Ability To Compose Effective Tests: Case Study From Manado, Indonesia \\ Cosmas Poluakan, State University of Manado, Indonesia
}

\begin{abstract}
This research was conducted to determine the effects of high scientific literacy, self-efficacy, and achievement motivation on teachers' ability to compose effective tests. It was conducted among junior high school science teachers in Manado, North Sulawesi Province, Indonesia, from April to September 2011, using a cross-sectional survey design. The instruments used in this research consist of questions to measure scientific literacy and teachers' ability to make tests, and questionnaires to investigate the self-efficacy and achievement motivation of teachers. A path analysis was used to test the hypothesis that there are direct positive effect of high scientific literacy and self-efficacy, as well as indirect effects through achievement motivation, on teachers' ability to compose effective tests. The results show positive influences of (1) high scientific literacy on achievement motivation; (2) self-efficacy on achievement motivation; (3) high scientific literacy on teachers' ability to make tests; and (4) achievement motivation toward teachers' ability to make tests. However, self-efficacy does not directly affect ability to make tests. The implications of this research are important for inservicelonservice programs (in which inservice refers to academic upgrading and onservice, to on-the-job training) for teachers, especially for those with teaching certificates (as opposed to teachers hired under the common practice of using 'honorary teachers', paid by stipend not salary, or volunteers).
\end{abstract}

Keywords: Scientific Literacy Mastery; Self-Efficacy; Achievement Motivation; Teachers' Ability to Compose Tests

\section{INTRODUCTION}

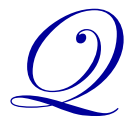

uality of education is largely determined by the quality of related personnel, such as educators, administrators, students, and stakeholders (Jusuf, 2005). The measures of quality in education can be viewed from two perspectives: first, the competencies and skills of educational actors (students, teachers, education personnel, and other interested parties; second, the processes used in and quality of outcomes assessment (Manjula \& Vaideeswaran, 2011; Omorogiuwa, 2012).

As a result of globalization, the demands on people in terms of competence and achievement are also increasing - the demands of world-class competence (Hayat \& Jusuf, 2010); and this will likely remain the case in the future. One important skill in a highly competitive era is scientific literacy (Holbrook \& Rannikmae, 2009). What is the reason for this? The Organization for Economic Co-operation and Development (OECD), which has implemented the Programme for International Student Assessment (PISA), argues that contemporary society is technologically based. Understanding the basic concepts and theories of science, and ability to organize and solve problems scientifically, has become increasingly important (OECD, 2007).

Based on the results of the PISA 2006 survey, involving 57 countries, Indonesia is below average scale on all three aspects of the assessment: identifying scientific issues, explaining phenomena scientifically, and using 
scientific evidence. On the first aspect, Indonesia scored 393 and ranks 53rd; on the second, 395 and 51st; and on the third, 386 and 50th (OECD, 2007). For comparison, in Finland, which first for all three aspects, the score were 555, 566, and 567, respectively. Even in 2009, despite some overall improvement, the position of Indonesia in scientific literacy remains below average, at 383 and 60th (OECD, 2010).

These results indicate that Indonesian scientific literacy is still lagging far behind that in many countries. Likewise, quality of education and quality of life in Indonesia remain low. As noted in the United Nations Development Programme's Human Development Report released in 2010, the Indonesia Human Development Index ranks 108th of 169 countries in the world. These data suggest many issues remain that need to be addressed to improve living standards and quality of knowledge and education.

One way in which this problem can be considered is in terms of the assessment of teacher effectiveness. There may be errors such as incorrect use of instruments in assessing level of competence and advancement of knowledge, attitudes, and skills, with the result that gaps are found which are not there or are smaller in reality (Stokking et al., 1999; Kocher et al., 2004; Greaney \& Kellaghan, 2008; Mansell et al., 2009; Ferguson et al., 2010).

The assessment (of students by teachers) component thus occupies a central position of this issue, in addition to the process, content, performance, and personnel components. Teachers carry out assessments to measure mastery of instructional materials and to get feedback on their work (Sanders, 2000; Joshua et al., 2006; Bumgarner \& Anthony, 2011; Omorigiuwa, 2012). Assessment should consist of both formative (performed in the process of learning) and summative (carried out to assess achievement in terms of learning outcomes at a certain time, as with school final exams) tests. Tests using materials prepared by the teacher are called teacher-made test (Harwell, 2003; Ussher \& Earl, 2010; Zaman et al., 2010; Oguzur \& Opara, 2011).

Empirical data reveal that in test results for junior and senior high school students, both formative (nonfinal exam) and summative tests tend not to correlate with scores on national final exams. That is, there are empirical issues with the substance of the tests, test implementation, and test benchmarks. For example, if the grade of physics subject of third grade junior high school students (14- and 15-year old students) is 8 (in report card, average of two semesters), then their national exam scores should be in this range as well. However, it has been found instead that when report card grades average 8, exam scores may be 4 or 5 (Samani, 2007). Why does this happen?

Every teacher wants to achieve, and a benchmark of teacher achievement is student achievement. If students get high scores in the (Indonesian) National Examination or pass the College Entrance Examination, their teacher is considered outstanding or successful. Thus, to achieve this type of success, learning is often tailored to the National Examination or College Entrance Examination (i.e., it is output oriented). Such behavior tends to occur because the teachers have the extrinsic motivation for recognition as well as the intrinsic motivation for student achievement, even if it is achieved by moving the goalposts (Maslow, 1943; Heylighen, 1992; Poston, 2009; Dima et al., 2010). Based on the theory of motivation and human needs of Maslow (Maslow, 1943), this tendency arises due to growth in motivation for self-fulfillment and self-actualization.

Achievement motivation and self-efficacy are related to level of knowledge mastery. This is clearly seen in OECD survey data on self-efficacy in science, in which Indonesia ranked last (OECD, 2007). This finding of low self-efficacy confirms a widespread phenomenon among students and teachers seen when the National Examination is held. Close to the National Examination, the anxiety levels of students and teachers tend to soar, as their selfconfidence is low (Locker \& Croplay, 2004; Ndirangu et al., 2009; Anyadubalu, 2010; Onyeizugbo, 2010).

Considering these low international achievement data and HDI, we need to reflect on some fundamental questions around the implementation of national education, adaptability of the curriculum, discrepancy between learning materials as science and technology change, a learning process that does not motivate students, and errors and inadequacies in assessment and test making. Even if all the processes, learning programs and curriculum used are sufficient, if instruments and assessment are inaccurate, the results will not reflect the real capabilities of the learners (Rudner \& Schafer, 2002). 
There are two types of measuring instruments used in this context: (1) standardized measuring instruments (standardized tests); and (2) measuring instruments created and developed by teachers (teacher-made and developed test) (Rudner \& Schafer, 2002; Zucker, 2003; Joshua et al., 2006). Creating standardized measurement tools requires a gradual, strictly regulated process. Standardized test questions should be collected in a question bank (Buyske, 2005; Pearson Education, 2005), and therein lies the problem of assessment in education. In general, educational institutions and educational administrative offices (such as the National Education Department) do not have standardized question banks. Thus, the assessment process is carried out using homemade measuring tools.

The range of measurements that must be undergone by students can include diagnostic (like the College Entrance Examination), formative, and/or summative tests (Rudner \& Schafer, 2002; McTighe \& O'Connor, 2005). The validity and reliability of teacher-made tests are not necessarily guaranteed (Bouzidi \& Jaillet, 2009; Skowronek et al., 2011). If assessment does not always feature strong measurement tools, it is worth exploring more deeply the factors that affect teachers making the tests. The factors examined in this study and suspected to affect teacher-made tests were scientific literacy, self-efficacy, and achievement motivation. Based on the background and conceptual framework outlined above, the hypothesis to be tested in this study, namely, there are direct positive effect of high scientific literacy and self-efficacy, as well as indirectly through achievement motivation on teachers' ability to compose effective tests.

\section{RESEARCH METHODOLOGY}

\section{Time, Place and Methods}

The study was conducted over six months, from April to September 2011, in Manado, North Sulawesi Province, Indonesia. The research method was a survey. The survey design can be placed in a research constellation as follows:

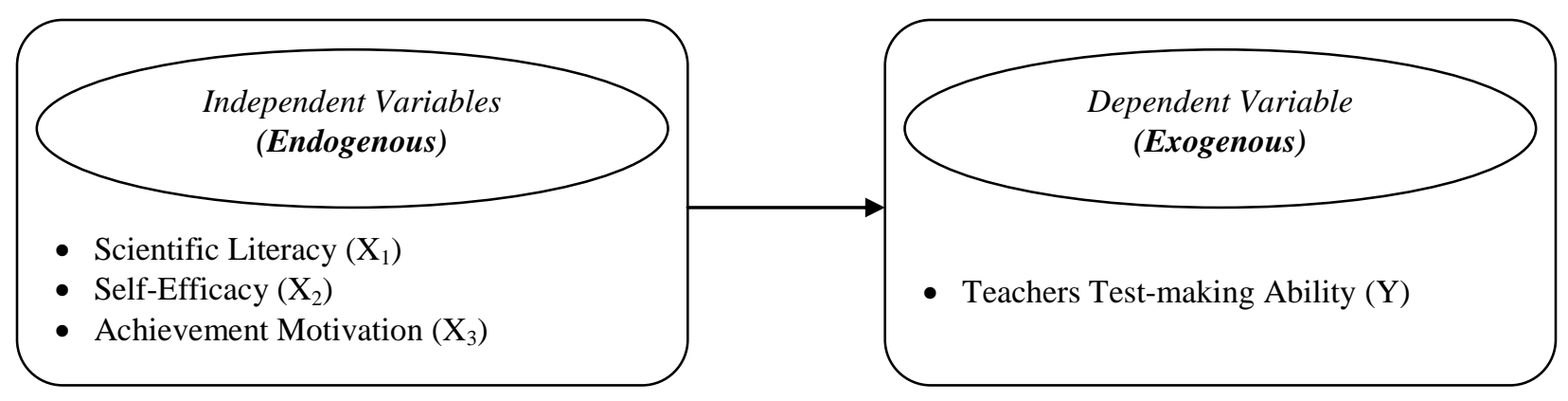

Figure 1. The research constellation

\section{Population and Sample}

The population of this study consisted of junior high school science teachers residing in Manado. According to with Central Bureau of Statistic of Manado data from 2009, there are 85 junior high schools in Manado, consisting of 14 state schools and 71 private schools, and 174 science teachers. The sample was selected using a proportional stratified sampling technique (Mertens, 2005). In all, 50\% of the teachers were taken from state schools and 50\% from private schools. Stratified sampling was by performance stratum according to the average value of science subjects on the National Examination in 2010. The school ranking was drawn from the National Standard Agency of Education (Indonesian acronym BSNP) and the Educational Assessment Center (Puspendik; BSNP \& Puspendik, 2010). Stratified sampling of respondents was as follows: 
Table 1. The number of included schools and respondent teachers

\begin{tabular}{|c|c|c|c|c|c|c|}
\hline \multirow[t]{2}{*}{ Stratum } & \multicolumn{2}{|c|}{ State Junior High School } & \multicolumn{2}{|c|}{ Private Junior High School } & \multirow{2}{*}{$\begin{array}{c}\text { Total Number } \\
\text { of Schools }\end{array}$} & \multirow{2}{*}{$\begin{array}{c}\text { Total Number of } \\
\text { Respondents }\end{array}$} \\
\hline & $\begin{array}{c}\text { Number of } \\
\text { Schools } \\
\end{array}$ & $\begin{array}{c}\text { Number of } \\
\text { Respondents }\end{array}$ & $\begin{array}{c}\text { Number of } \\
\text { Schools }\end{array}$ & $\begin{array}{c}\text { Number of } \\
\text { Respondents }\end{array}$ & & \\
\hline Higher & 3 & 6 & 5 & 12 & 8 & 18 \\
\hline Middle & 7 & 21 & 7 & 12 & 14 & 33 \\
\hline Lower & 2 & 3 & 5 & 6 & 7 & 9 \\
\hline Total & 12 & $30(50 \%)$ & 17 & $30(50 \%)$ & 29 & 60 \\
\hline
\end{tabular}

\section{Data Collection}

\section{Instrument Preparation}

The instruments used in this study were two: first, a multiple-choice objective test with four answer choices for the Scientific Literacy $\left(\mathrm{X}_{1}\right)$ and Teacher Test-making Ability (Y) variables; and second, a questionnaire (using a Likert scale) for the Self-Efficacy $\left(\mathrm{X}_{2}\right)$ and Achievement Motivation $\left(\mathrm{X}_{3}\right)$ variables. The steps of preparation were as follows: (1) development of indicators and ratings; (2) preparation of instruments; (3) expert validation; (4) validity and reliability tests; (5) revision; (6) finalization; and (7) data collection.

\section{Analysis of Test Instrument}

For the multiple-choice instrument (variables $\mathrm{Y}$ and $\mathrm{X}_{1}$ ), which consisted of 50 questions, three stages of test analysis were applied. First, different power and difficulty level of items were applied using a discriminant index $(\mathrm{P})$ with acceptance criteria $\rho_{i a}>0.2$; second was a test of validity using a point biserial correlation coefficient; and third, a test of reliability using the internal consistency reliability coefficient of Kuder-Richardson Formula 20 (KR-20) with the criteria $\rho_{\text {reliability }}>0.9$. For the Likert instruments (variables $\mathrm{X}_{2}$ and $\mathrm{X}_{3}$ ), which used a 50-item questionnaire, validity and reliability analyses were applied. The validity test was performed using the Pearson Product-Moment Correlation Coefficient, while the reliability test used Cronbach's Alpha, with an acceptance criterion of $\mathrm{r}_{\text {arithmetic }}>\mathrm{r}_{\text {table }}$ (Tucker, 2007).

\section{Data Processing}

\section{Dichotomous Data}

For the $\mathrm{X}_{1}$ variable, there were selected the 35 (of 50) items that met the discriminant index, validity, and reliability criteria. Thus, scores could range from 0 to 35 . For variable $Y$ were selected 36 of 50 items, so scores could range from 0 to 36 . These raw scores were converted to a range of 0-100 (Kumar \& Annie, 2012).

\section{Continuous Data}

The scores obtained from each respondent, both favorable and unfavorable, were processed into an attitude scale with normal deviation. Response values were scored from 0 to 4 . Based on the variation of the response scores on each item, the total maximum score for all items of variable $\mathrm{X}_{2}$ was 89 and minimum score was 0 . Meanwhile, the maximum score for all items of $\mathrm{X}_{3}$ was 84 and the minimum, 0 .

\section{Data Analysis}

To determine the significance of the relationships between variables, data were analyzed using path analysis, with the help of LISREL version 8.80 (Scientific Software International, Inc., Skokie, IL, 2006). Path analysis as a multivariate analysis is an extension of the regression model, which is used to test the suitability of the correlation matrix against two or more causal models, which are compared by the researchers. This statistical analysis can be applied if the data meets certain normality and linearity requirements (Mels, 2006; Lei \& Wu, 2007; Hoe, 2008; Yamin \& Kurniawan, 2009). 


\section{RESULTS}

\section{The Model of Path Analysis}

The process of hypothesis testing in path analysis can be described by the structural model that follows:

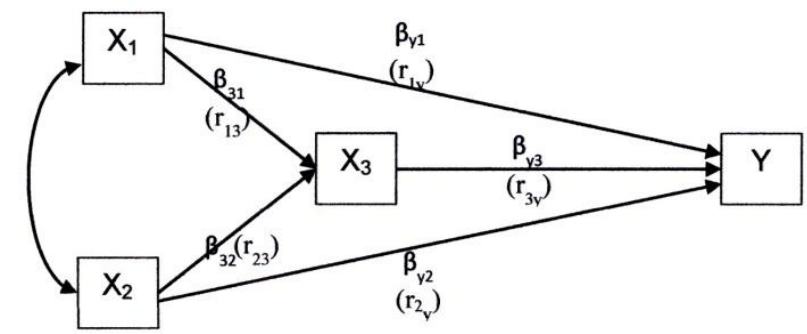

Figure 2. Structural model of path analysis

For the purposes of calculating the path coefficient, the structural model is divided into 2 substructures, respectively (1) substructure 1 , including variables $X_{1}, X_{2}$, and $X_{3}$; and (2) substructure 2 , including $X_{1}, X_{2}, X_{3}$, and $Y$.

\section{Pathway Coefficient of Substructure 1} below:

The calculation analysis model of the of pathway coefficient of substructure 1 is expressed in the equation

$X_{3}=\rho_{31} X_{1}+\rho_{32} X_{2}+\rho_{321} \varepsilon_{1}$

A hypothetical model of path analysis of substructure 1 and the calculation of the correlation and inverse matrix to determine the correlation coefficient is shown in Figure 3 below:

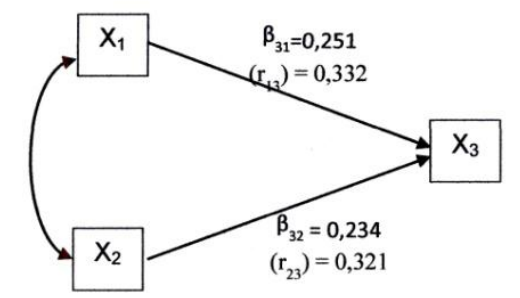

Figure 3. Pathway and correlation coefficients of substructure 1

\section{Pathway Coefficient of Substructure 2} below:

A model of calculation analysis of the pathway coefficient of substructure 2 is expressed in the equation

$\mathrm{Y}=\rho_{\mathrm{y} 1} \mathrm{X}_{1}+\rho_{\mathrm{y} 2} \mathrm{X}_{2}+\rho_{\mathrm{y} 3} \mathrm{X}_{3}+\rho_{\mathrm{y} 321} \varepsilon_{2}$

A hypothetical model of path analysis of substructure 2 and the calculation of the correlation and inverse matrix to determine the correlation coefficient is shown in Figure 4 below: 


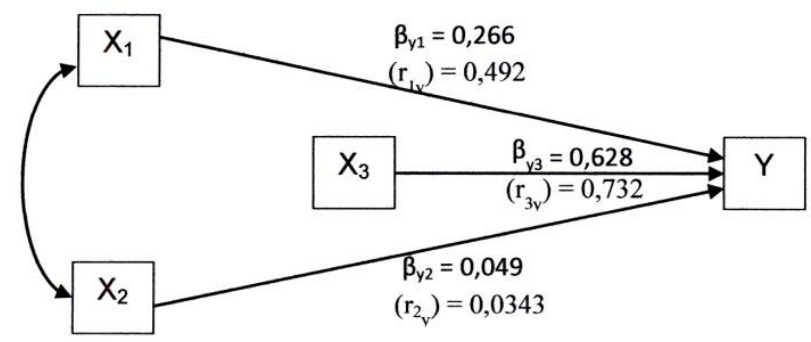

Figure 4. Pathway and correlation coefficients of substructure 2

\section{Pathway Coefficients of Overall Variables}

The merger of the two substructure models was given by the LISREL printout (Figure 5) as follows:

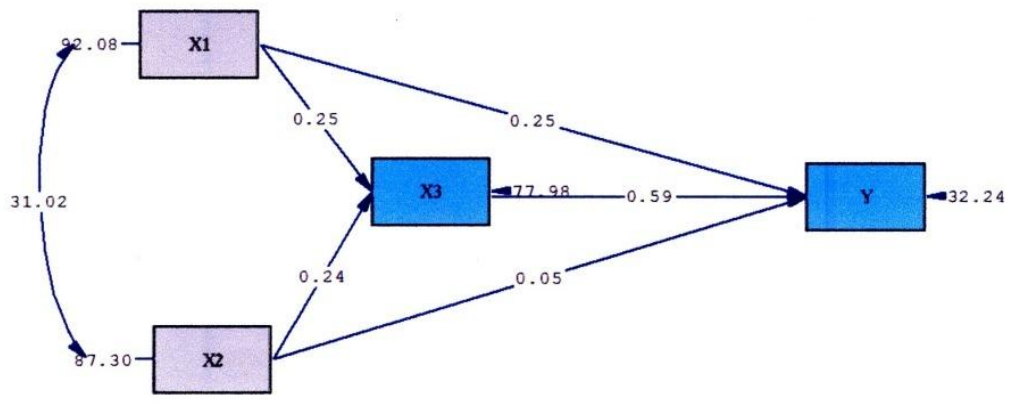

Figure 5. The overall value of pathway coefficients

The relationships between the hypothetical predictor constructs $\left(X_{1}, X_{2}\right.$, and $X_{3}$, the endogenous/independent variables) and teachers' ability to make tests ( $\mathrm{Y}$, the exogenous/dependent variable) is shown in Figure 5 above. The direct effects of scientific literacy $\left(\mathrm{X}_{1}\right)$ and achievement motivation $\left(\mathrm{X}_{3}\right)$ on teachers' ability to make tests $(\mathrm{Y})$ were significant (the pathway coefficients were 0.25 and 0.59 , respectively), but selfefficacy $\left(\mathrm{X}_{2}\right)$ showed no significant predictive value for teachers' ability to make tests (the pathway coefficient was $0.05)$.

\section{DISCUSSION}

\section{Positive Effect of Scientific Literacy on Achievement Motivation}

Scientific literacy is closely related to the process, content, and context components of science. Someone who has good scientific literacy has proficiency in identifying, analyzing and solving scientific problems and drawing conclusions based on facts. A science teacher who has good scientific literacy is capable of understanding the development of science and technology in everyday life, reflecting critically on the information received, and becoming more confident in discussions on scientific issues (Holbrook \& Rannikmae, 2009; Liu, 2009). High scientific literacy will provide enlightenment and shape the personality itself to uphold the truth (by predicated on yet another important value - freedom), as well as manifests an underlying system of values like skepticism, originality, consistency/order, and communication (Abruscato, 1982).

Associated to the relationship between scientific literacy with truth and freedom, Abruscato (1982) stated that, "Since science seeks to explain truth and make sense out of our natural world, it has as its most basic value the search for truth. The scientist seeks to discover not what should be but rather what is. The high value placed on truth applies not only to the discovery of facts, concepts, and principles, but also to the recording and reporting of such knowledge. The search for truth is predicated on yet another important value-freedom. Real science occurs only when the investigator is able to operate in an environment that provides him or her with the freedom to follow paths 
wherever they may lead. History is full of examples of scientists who had to pay a very high price for publicly affirming the results of their work."

Someone with achievement motivation is someone who has intrinsic motivation, is constantly growing and developing, makes an effort to achieve goals, and perseveres to successfully complete the job. Therefore, professional teachers who have achievement motivation will try to complete their tasks without troubling others, focus on goals, work hard, finish on time, focus on achieving success and avoiding failure, never give up when faced with a difficult task, and most importantly, have the ability to self-motivate (Elliot \& Church, 1997; Ibrahim \& Gwari, 2011).

The effect of scientific literacy on achievement motivation is seen, as the reader will note. The effect functions through the habit of identifying, analyzing, and solving problems. Tasks are executed with passion, calculation, and forethought. A person who is accustomed to think in a scientifically literate way can uphold honesty and truth, give priority to productivity and originality of ideas, work consistently, communicate, and able to operate independently (Abruscato, 1982; Osborne, 2007; Hanrahan, 2009; Praputtakun et al., 2012).

\section{Positive Effect of Scientific Literacy on Teachers' Ability to Make Tests}

Teachers' scientific literacy and their ability to make tests can be measured in terms of their maximum performance. A teacher can make a good test if his or her intellectual capability is adequate to have mastered the subject matter. Science teachers are science workers, because in addition to having the ability to transfer scientific knowledge they are also directly involved in work in laboratories. As a scientific worker, the teacher requires powers of observation and logical thinking, and science teachers are also required to think experimentally. This ability to think is what makes science teachers able to design and produce as well as implement their work (Norris \& Phillips, 2003; Weinstein, 2009; Koksal \& Cakiroglu, 2010).

Creating a test instrument means making a measurement tool. This requires an internally consistent thought process and requires the ability to formulate instructions, set indicators, know the standards of educational assessment, use operational verbs, vary tests, and assess question items. Thus, it can be said that teachers who have good science literacy simultaneously have the ability to make a good test.

Although, based on the results in this research, scientific literacy has direct as well as indirect (by means of achievement motivation) effects on teachers' ability to make tests, it was argued by DeBoer (2000) that, "Instead of defining scientific literacy in terms of specifically prescribed learning outcomes, scientific literacy should be conceptualized broadly enough for local school districts and individual classroom teachers to pursue the goals that are most suitable for their particular situations along with the content and methodologies that are most appropriate for them and their students. This would do more to enhance the public's understanding and appreciation of science than will current efforts, which are too narrowly aimed at increasing scores on international tests of science knowledge." DeBoer (2000) added that. "A broad and open-ended approach to scientific literacy would free teachers and students to develop a wide variety of innovative responses to the call for an increased understanding of science for all."

\section{Positive Effect of Self-Efficacy on Achievement Motivation}

Self-efficacy is the belief in the self-owned capability to be able to complete tasks thoroughly (Bandura, 1977; Bandura, 1982). Self-efficacy as a manifestation of self-belief is an innate or latent ability. For a teacher, selfefficacy is the confidence that she or he is very capable of doing his or her job and making a positive contribution to the improvement of his or her own competence and the success of the learners under his or her charge. Self-efficacy triggers creativity and creative activities that are valued and effective in meeting the demands of the teaching profession. There will be increased satisfaction in activities implemented by these teachers, and they will develop pride in the benefits they can provide for students, peers, their school, and the community (Tschannen-Moran \& Hoy, 2001; Chacón, 2005; Azar, 2010; Bembenutty, 2010; Narayan \& Lamp, 2010; Skaalvik \& Skaalvik, 2010). 
Basically, people have an attitude toward their work that should be fostered and kept positive to achieve their goal. Motivation can push people to work with effort and perseverance, make decisions independently, focus on goals, work hard and finish on time, and be a "success seeker", as termed by Atkinson (1964). People with high achievement motivation have pride in their productivity, are independent and flexible, have self-control, are not afraid, and never give up when faced with a difficult task. Professional teachers who have high achievement motivation seek to build an impressive career, improve their abilities and skills as demanded by authorities, maintain the dignity of the noble profession of educator, autonomously make decisions in the workplace, and uphold a professional commitment to the client (the learner) (Schunk, 1991; Pajares, 2003; Bleicher, 2004; Senemoĝlu et al., 2009; Skaalvik \& Skaalvik, 2009; Cheng \& Chiou, 2010; Dibapile, 2012) as per the Indonesian teachers' code of ethics.

The effect of teacher self-efficacy toward achievement motivation lies in the belief that "I can," and will appear in the spirit of the teacher. If the "I can" belief is an impulse that arises from the inner self, then a spirit full of joy and excitement that is creative, diligent, patient, persistent, and disciplined in work will be seen in the outer self (Weaver, 2008). Teachers who have high self-efficacy in addition should be able to motivate themselves and their co-workers and shape the character of their students. The effect of teacher self-efficacy toward achievement motivation will appear in the way they meet the profession's demands as a whole (as educator, facilitator, counselor, and motivator).

\section{Positive Effect of Achievement Motivation on Teachers' Ability to Make Tests}

Manufacturing test instruments requires logical skills and observation ability. A teacher is charged with more than just the ability to understand the substance of teaching materials - he or she also needs understanding and implementation ability to create well-designed, well-developed, and well-manufactured instruments according to standards. These capabilities, among others, rely on a good understanding of the theory of the measurement, preparation, and development of standardized instruments. Because the task requires so many different abilities, the inner self of the teacher must develop achievement motivation, as seen in efforts to achieve progress, persevere in one's work, love the challenge, focus on the goals, work without burdening others, take pride in productivity, and so on (Bracey, 2000; Hanlon, 2005; Butler \& Shibaz, 2008; Kudzai et al., 2011; Trumbull \& Rothstein-Fisch, 2011).

If the spirit of achievement motivation has not grown well, the teachers will tend not to make their own tests, and will instead just appropriate questions that are available in reference books or question packages provided by other parties. This issue is referred to by Samani (2007) as the approach to output and outcome assessment. Educational expectations often affect teaching methods and learning patterns, especially at the regional and national levels of assessments. For example, when facing the National Examination (UN) or the College Entrance Examination (UMPT), teachers sometimes change their classroom approaches to help their students achieve good results. Every teacher wants to achieve, and one performance benchmark is the achievement of their students.

The National Examination on the one hand helps us to some degree to determine the quality of education provided in the educational unit, but on the other hand raises the casuistic issue. For example, there is the question of the tendency of teachers who take shortcuts and do not create their own questions but instead take test materials from the UN or UMPTN tests or from other sources. Ostensibly, the formative and summative tests that are implemented in the classroom are compiled by teachers themselves. With the increasing expectation that this will be the case (and that tests will be designed based on the nationally established Competency Standards (for general instructional objectives) and Basic Competence (for specific instructional objectives)), it is expected that in subsequent years assessment processes will further reduce the difference between grades on report cards and UN results.

\section{Self-Efficacy and Teachers' Ability to Make Tests}

Self-efficacy exists in every person in different levels. People have different base levels of self-efficacy and different levels of opportunity to achieve the same performance behavior. Knowing the attitude of a person does not necessarily mean that we can predict his or her behavior with high accuracy. That is, high self-efficacy is not alone able to complete tasks such as creating a test instrument. Inconsistency between attitudes and behavior arises partly 
from the individual's orientation to a given situation at a given time. This argument was presented by Warner and DeFleur (1969), who proposed three postulates in identifying the relationship between attitudes and behavior: (1) consistency, which assumes that there is a direct relationship between attitudes and behavior; (2) independent variations, which revealed that there is no reason to conclude that attitudes and behaviors are consistently related (i.e., that inconsistencies occur between attitudes and behavior), and that attitudes and behavior are two-dimensional qualities that stand alone, separate and distinct, within the individual; and (3) dependent consistency, which states that attitudes and behavior are largely determined by specific situational factors.

Based on the postulate of independent variations, we see that a person can have high self-efficacy but not the ability to make an effective test instrument or other evaluation tools. Self-efficacy can provide discipline, confidence, creativity, and other beneficial results. However, it may not be conducive to having more ability, skill, or expertise. Confidence in self-reliability, which is an innate ability, it is not quite adequate if an individual does not have the firmness of principle and perseverance to push forward and is unable to face challenges.

In this study, inconsistencies between attitudes and behavior are shown in the nature of the relationship between teachers' self-efficacy $\left(\mathrm{X}_{2}\right)$ and ability to make tests $(\mathrm{Y})$. Based on the inconsistency postulate, not every person who has high self-efficacy will immediately be able to show concrete high performance. Self-efficacy is a potential or innate ability, whereas teachers' ability to make tests is requires concrete performance resting on cognitive capabilities, shown in the form of achievement scores. In Festinger's view, humans are always logical and motivated to maintain cognitive consistency, but also have to deal with the fact that human behavior is often irrational (Festinger \& Carlsmith, 1959). This opinion leads to a justification of why not all teachers who have high self-efficacy are able to make a good test. Good test-making ability requires special competencies and more knowledge of the theory of measurement, psychometric theory, instrument development, program evaluation, and other related competencies.

\section{CONCLUSION AND SUGGESTIONS}

The results of this study show that the scientific literacy of junior high school science teachers in the city of Manado, Indonesia, has a positive influence on their ability to make tests, both directly and indirectly. Directly, a good understanding of the content and the procedures and terms of the test is a prerequisite for making the evaluation instrument. This prerequisite is easily satisfied by science teachers, because as science workers they have been accustomed to relaying or transferring scientific knowledge. Science teachers are also accustomed in experimental thinking, so they have good competence in designing, implementing, and producing work such as instruments for measuring learning outcomes.

Indirectly, the positive influence of scientific literacy on ability to make tests is due to the encouragement of achievement motivation from within the inner self of the teacher. Accustomed to think and act as a scientifically literate person, the teacher will develop increasing professionalism over time. High scientific literacy and the habit of identifying, analyzing, and solving problems will motivate teachers to achieve. If the spirit of achievement motivation has not grown well, however, then the teacher will tend not to make his or her own test but will just employ questions available in reference books or question packages provided by third parties.

In contrast to science literacy, the self-efficacy of junior high school science teachers does not have a direct positive influence on their ability to make tests, but influence is it indirectly through the encouragement of achievement motivation. Indirectly, self-efficacy as a manifestation of confidence in completing tasks greatly affects the achievement motivation of teachers. Like a machine, achievement motivation acts as the "gears," which spin smoothly when there is a "lubricant" named self-efficacy. Why does self-efficacy of teachers not directly impact their teachers to make tests? High self-efficacy is not alone able to complete tasks such as this. Inconsistency or discrepancy between attitudes and behavior is possible, for instance due to the individual's orientation to the situation at any given time. Human beings are always to some degree logical and motivated to maintain cognitive consistency, but also have to deal with the fact that human behavior is often irrational.

The finding that high scientific literacy in science teachers has a positive impact toward their ability to make tests (both directly and, through the encouragement of motivation to achieve, indirectly), as well as the finding 
that teacher self-efficacy does not alone make a positive impact, encourages the present author to provide specific advice that needs to be considered when conducting onservice programs for professional teachers or inservice programs for prospective teachers. Such programs may include education and training aiming to improve science literacy, self-efficacy, and achievement motivation (the present paper's endogenous variables), and may have a positive impact on the ability of teachers to make tests (the exogenous variable).

In addition, the author suggests that an evaluation consultant should be provided at each school. Advice can be given based on the finding that self-efficacy does not have a direct effect, implying the need to improve guidance programs (particularly with regard to character-building) for science teachers, implemented either by the principal or by competent authorities. Generally, advice given to enhance teachers' test-making ability should recommend advanced education programs (master's and doctoral degrees) in the fields of research and evaluation in education as well as psychometrics. Improvement in the variables (both endogenous and exogenous) discussed in the present paper will of course in turn improve the quality of the product. Thus, the dignity and prestige of Indonesia will increase as a result of improved Human Development Index and other international survey indicators.

\section{AUTHOR BIOGRAPHY}

Cosmas Poluakan is a lecturer at the Department of Physics Education and has also served as the Dean of the Faculty of Mathematics and Natural Sciences of the State University of Manado in Indonesia. He has taught elementary physics, mechanics, modern physics, seismology, evaluation of physics learning, assessment of sciences learning, and introduction to education. He holds the following qualifications: Bachelor of Education with a concentration in Physics, State University of Manado (Indonesia); Master of Science in Physics, Gadjah Mada University (Indonesia); and Doctor of Education with a specialization in research and evaluation, State University of Jakarta (Indonesia). His research interests are the development of scientific literacy instruments, the development of scientific literacy teaching materials, the development of models of science question banks, and the measurement of information technology-based science learning. E-mail: cpoluakan@mail.unima.ac.id

\section{REFERENCES}

1. Abruscato, J. (1982). Teaching Children Science. Englewood Cliffs, N.J.: Prentice-Hall, Inc.

2. Anyadubalu, C. C. (2010). Self-Efficacy, Anxiety, and Performance in the English Language among Middle-School Students in English Language Program in Satri Si Suriyothai School, Bangkok. International Journal of Human and Social Sciences, 5(3) 193-198.

3. Atkinson, J. W. (1964). An Introduction to Motivation. Princeton, NJ: Van Nostrand.

4. Azar, A. (2010). In-service and Pre-service Secondary Science Teachers' Self-efficacy Beliefs about Science Teaching. Educational Research and Reviews, 5(4) 175-188.

5. Bandura, A. (1977). Self-efficacy: Toward a Unifying Theory of Behavioral Change. Psychological Review, 84(2) 191-215.

6. Bandura, A. (1982). Self-Efficacy Mechanism in Human Agency. American Psychologist, 37(2) 122-147.

7. Bembenutty, H. (2010). Homework Completion: The Role of Self-efficacy, Delay of Gratification, and Self-Regulatory Processes. The International Journal of Educational and Psychological Assessment, 6(1) $1-20$.

8. Bleicher, R. E. (2004). Revisiting the STEBI-B Measuring Self-Efficacy in Preservice Teachers. School Science and Mathematics, 105(8) 383-391.

9. Bouzidi, L. \& Jaillet, A. (2009). Can Online Peer Assessment be Trusted? Educational Technology \& Society, 12(4) 257-268.

10. Central Bureau of Statistic of Manado. (2009). Statistics of Manado City in 2009. Manado: Central Bureau of Statistic. [Indonesia]

11. Bracey, G. W. (2000). Thinking about Tests and Testing: A Short Primer in "Assessment Literacy". Washington, DC: American Youth Policy Forum.

12. BSNP \& Puspendik (2010). Report: The Result of National Exam in 2009/2010 School Year. Jakarta: National Standard Agency of Education (BSNP) \& Educational Assessment Center (Puspendik). [Indonesia] 
13. Bumgarner, H. \& Anthony, K. (2011). Teacher Evaluation: Artifacts that Document How the Work of the Teacher Results in Student Academic Progress. Virginia: Metropolitan Educational Research Consortium (MERC), Virginia Commonwealth University.

14. Butler, R. \& Shibaz, L. (2008). Achievement Goals for Teaching as Predictors of Students' Perceptions of Instructional Practices and Students' Help Seeking and Cheating. Learning and Instruction, 18 453-467.

15. Buyske, S. (2005). Optimal Design in Educational Testing. In: Berger, M. P. F. \& Wong, W. K. (Eds.). Applied Optimal Designs. New Jersey: John Wiley \& Sons, Ltd.

16. Chacón, C. T. (2005). Teachers' Perceived Efficacy among English as A Foreign Language Teachers in Middle Schools in Venezuela. Teaching and Teacher Education, 21 257-272.

17. Cheng, P. Y. \& Chiou, W. B. (2010). Achievement, Attributions, Self-Efficacy, and Goal Setting by Accounting Undergraduates. Psychological Reports, 106 1-11.

18. DeBoer, G. E. (2000). Scientific Literacy: Another Look at Its Historical and Contemporary Meanings and Its Relationship to Science Education Reform. Journal of Research in Science Teaching, 37(6) 582-601.

19. Dibapile, W. T. S. (2012). A Review of Literature on Teacher Efficacy and Classroom Management. Journal of College Teaching \& Learning, 9(2) 79-91.

20. Dima, I. C., Man, M. \& Kot, S. (2010). Use of Abraham Maslow's Motivation Theory for Setting Consumers' Satisfaction-Non-Satisfaction. Polish Journal of Management Studies, 2(1) 132-138.

21. Elliot, A. J. \& Church, M. A. (1997). A Hierarchical Model of Approach and Avoidance Achievement Motivation. Journal of Personality and Social Psychology, 72(1) 218-232.

22. Ferguson, R. F., Hackman, S., Hanna, R. \& Ballantine, A. (2010). How High Schools Become Exemplary: Ways that Leadership Raises Achievement and Narrows Gaps by Improving Instruction in 15 Public High Schools. Report on the 2009 Annual Conference of the Achievement Gap Initiative at Harvard University.

23. Festinger, L. \& Carlsmith, J. M. (1959). Cognitive Consequences of Forced Compliance. Journal of Abnormal and Social Psychology, 58 203-210.

24. Greaney, V. \& Kellaghan, T. (2008). National Assessments of Educational Achievement (Volume 1): Assessing National Achievement Levels in Education. Washington, DC: The International Bank for Reconstruction and Development/The World Bank.

25. Hanlon, B. (2005). Adding Standardized and High Stakes Test-style Questions to Teacher-made Tests in High School Mathematics. Nevada: Southern Nevada Regional Professional Development Program.

26. Hanrahan, M. (2009). Bridging the Literacy Gap: Teaching the Skills of Reading and Writing as They Apply in School Science. Eurasia Journal of Mathematics, Science \& Technology Education, 5(3) 289304.

27. Harlen, W. (2005). Teachers' Summative Practices and Assessment for Learning - Tensions and Synergies. The Curriculum Journal, 16(2) 207-223.

28. Harwell, S. H. (2003). Teacher Professional Development: It's Not an Event, It's a Process. Texas: CORD.

29. Hayat, B. \& Yusuf, S. (2010). International Benchmark of Education Quality. Jakarta: Bumi Aksara Publisher. [Indonesian]

30. Heylighen, F. (1992). A Cognitive-Systemic Reconstruction of Maslow's Theory of Self-Actualization. Behavioral Science, 37 39-57.

31. Hoe, S. L. (2008). Issues and Procedures in Adopting Structural Equation Modeling Technique. Journal of Applied Quantitative Methods, 3(1) 76-83.

32. Holbrook, J. \& Rannikmae, M. (2009). The Meaning of Scientific Literacy. International Journal of Environmental \& Science Education, 4(3) 275-288.

33. Ibrahim, M. \& Gwari, P. (2011). A Study of Achievement Motivation of Low and High Level Volleyball Players. Journal of Educational and Practice, 2(11\&12) 14-16.

34. Joshua, M. T., Joshua, A. M. \& Kritsonis, W. A. (2006). Use of Student Achievement Scores as Basis for Assessing Teachers' Instructional Effectiveness: Issues and Research Results. National Forum of Teacher Education Journal, 17(3) 1-13.

35. Jusuf, H. (2005). Improving Teacher Quality, A Keyword for Improving Education Facing Global Challenges. The Turkish Online Journal of Educational Technology, 4(1) 33-37.

36. Kocher, T., Schellenberg, S., Sireci, S. G., Jorgensen, M., McCreadie, J., Ligon, G. \& O'Reilly, J. (2004). The Achievement Gap: Test Bias or School Structures? National Association of Test Directors 2004 Annual Proceedings. 
37. Koksal, M. S., \& Cakiroglu, J. (2010). Examining Science Teacher's Understandings of the NOS Aspects through the Use of Knowledge Test and Open-Ended Questions. Science Education International, 21(3) 197-211.

38. Kudzai, C., Moses, K. \& Emily, G. (2011). Quality or Mere Formality? Food For Thought in the Use of Teacher-Made Tests in Masvingo Rural Secondary Schools in Zimbabwe. Journal of Emerging Trends in Educational Research and Policy Studies, 2(6) 418-425.

39. Kumar, D. A. \& Annie, L. C. (2012). Clustering Dichotomous Data for Health Care. International Journal of Information Sciences and Techniques, 2(2) 23-33.

40. Lei, P. W. \& Wu, Q. (2007). An NCME Instructional Module on Introduction to Structural Equation Modeling: Issues and Practical Considerations. Educational Measurement: Issues and Practice, 26(3) 3344.

41. Liu, X. (2009). Beyond Science Literacy: Science and the Public. International Journal of Environmental \& Science Education, 4(3) 301-311.

42. Locker, J. \& Cropley, M. (2004). Anxiety, Depression and Self-Esteem in Secondary School Children: An Investigation into the Impact of Standard Assessment Tests (SATs) and other Important School Examinations. School Psychology International, 25(3) 333-345.

43. Manjula, R. \& Vaideeswaran, J. (2011). A New Framework for Measuring the Quality of Engineering Education System using SEI-CMM Approach - ( $\left.\mathrm{E}^{2}-\mathrm{CMM}\right)$. International Journal of Software Engineering \& Applications, 2(1) 28-43.

44. Mansell, W., James, M. \& The Assessment Reform Group (2009). Assessment in Schools. Fit for Purposes? A Commentary by The Teaching and Learning Research Programme. London: Economic and Social Research Council, Teaching and Learning Research Programme.

45. Maslow, A. H. (1943). A Theory of Human Motivation. Psychological Review, 50(4) 370-396.

46. McTighe, J. \& O'Connor, K. (2005). Seven Practices for Effective Learning. Educational Leadership, 63(3) 10-17.

47. Mels, G. (2006). LISREL for Windows: Getting Started Guide. Lincolnwood, Illinois: Scientific Software International, Inc.

48. Mertens, D. M. (2005). Research and Evaluation in Education and Psychology - Integrating Diversity with Quantitative, Qualitative, and Mixed Methods, 2nd Edition. California: Sage Publications, Inc.

49. Narayan, R. \& Lamp, D. (2010). "Me? Teach Science?" Exploring EC-4 Pre-service Teachers' Self Efficacy in An Inquiry-based Constructivist Physics Classroom. Educational Research and Review, 5(12) 748-757.

50. Ndirangu, G. W., Muola, J. M., Kithuka, M. R. \& Nassiuma, D. K. (2009). An Investigation of the Relationship between Test Anxiety and Academic Performance in Secondary Schools in Nyeri District, Kenya. Global Journal of Educational Research, 8(1\&2) 1-8.

51. Norris, S. P. \& Phillips, L. M. (2003). How Literacy in Its Fundamental Sense Is Central to Scientific Literacy. Science Education, 87(2) 224-240.

52. Oguzor, N. S. \& Opara, J. A. (2011). Evaluation and Measurement in High School Education. Current Research Journal of Social Sciences, 3(4) 364-373.

53. Omorogiuwa, K. O. (2012). Teacher Quality Assessment Measures as Predictors of Students' Achievement. International Journal of Social Science Tomorrow, 1(3) 1-7.

54. Onyeizugbo, E. U. (2010). Self-Efficacy, Gender and Trait Anxiety as Moderators of Test Anxiety. Electronic Journal of Research in Educational Psychology, 8(1) 299-312.

55. Organization for Economic Co-operation and Development (OECD) (2007). PISA 2006 - Science Competencies for Tomorrow's World - Volume 1: Analysis. Corrigenda: OECD Publication.

56. Organization for Economic Co-operation and Development (OECD) (2010). PISA 2009 Results: What Students Know and Can Do - Student Performance in Reading, Mathematics and Science (Volume 1). Corrigenda: OECD Publication.

57. Osborne, J. (2007). Science Education for the Twenty First Century. Eurasia Journal of Mathematics, Science \& Technology Education, 3(3) 173-184.

58. Pajares, F. (2003). Self-Efficacy Beliefs, Motivation, and Achievement in Writing: A Review of The Literature. Reading \& Writing Quarterly, 19 139-158.

59. Pearson Education, Inc. (2005). Comparing Standards-based Item Banks and Pre-built Tests for Classroom Assessment: Assessment Report. Texas: Pearson Education, Inc. 
60. Poston, B. (2009). An Exercise in Personal Exploration: Maslow's Hierarchy of Needs. The Surgical Technologist, August 347-353.

61. Praputtakun, P., Dasah, C., Tambanchong, C., Meatepinitkul, P. \& White, O. L. (2012). The Effect of Using Philosopher's Heart Principle on Primary School Students' Scientific Literacy and Language Abilities: The Study in Thailand. Proceedings of International Conference on Education and Management Innovation, IACSIT Press, 156-160.

62. Rudner, L. \& Schafer, W. (2002). What Teachers Need to Know About Assessment. Washington, DC: National Education Association.

63. Samani, M. (2007). Initiated A Meaningful Education. Surabaya: SIC Publisher. [Indonesian]

64. Sanders, W. L. (2000). Value-Added Assessment from Student Achievement Data: Opportunities and Hurdles. Journal of Personnel Evaluation in Education, 14(4) 329-339.

65. Schunk, D. H. (1991). Self-Efficacy and Academic Motivation. Educational Psychologist, $26207-231$.

66. Senemoĝlu, N., Demirel, M., Yaĝci, E. \& Üstündaĝ, T. (2009). Elementary School Teachers' Self-Efficacy Beliefs: A Turkish Case. Humanity \& Social Sciences Journal, 4(2) 164-171.

67. Skaalvik, E. M. \& Skaalvik, S. (2009). Self-Concept and Self-Efficacy in Mathematics: Relation with Mathematics Motivation and Achievement. Journal of Education Research, 3(3) 255-278.

68. Skaalvik, E. M. \& Skaalvik, S. (2010). Teacher Self-efficacy and Teacher Burnout: A Study of Relations. Teaching and Teacher Education, 26 1059-1069.

69. Skowronek, J., Friesen, B. \& Masonjones, H. (2011). Developing a Statistically Valid and Practically Useful Student Evaluation Instrument. International Journal for the Scholarship of Teaching and Learning, 5(1), retrieved from: http://academics.georgiasouthern.edu/ijsotl/v5n1.html

70. Stokking, K., van Aert, L., Meijberg, W. \& Kaskens, A. (1999). Evaluating Environmental Education. Cambridge: International Union for Conservation of Nature and Natural Resources.

71. Trumbull, E. \& Rothstein-Fisch, C. (2011). The Intersection and Achievement Motivation. The School Community Journal, 21(2) 25-54.

72. Tschannen-Moran, M. \& Hoy, A. W. (2001). Teacher Efficacy: Capturing An Elusive Construct. Teaching and Teacher Education, 17 783-805.

73. Tucker, S. (2007). Using Remark Statistics for Test Reliability and Item Analysis. Baltimore: University of Maryland, School of Pharmacy.

74. United Nations Development Programme (UNDP) (2010). Human Development Report 2010: 20th Anniversary Edition - The Real Wealth of Nations: Pathways to Human Development. New York: Palgrave Macmillan.

75. Ussher, B. \& Earl, K. (2010). 'Summative' and 'Formative': Confused by the Assessment Terms? New Zealand Journal of Teachers' Work, 7(1) 53-63.

76. Warner, L. G. \& DeFleur, M. L. (1969). Attitude as An Interactional Concept: Social Constraint and Social Distance as Intervening Variables Between Attitudes and Action. American Sociological Review, 34(2) 153-169.

77. Weaver, J. (2008). The Effect of Self-efficacy on Motivation and Achievement among Fifth Grade Science Students. Thesis of Master of Education, Ohio University.

78. Weinstein, M. (2009). Critical Science Literacy: Identifying Inscription in Lives of Resistance. Journal for Activist Science \& Technology Education, 1(2) 1-11.

79. Yamin, S. \& Kurniawan, H. (2009). Structural Equation Modeling - Statistic Application Book, 2nd Volume. Jakarta: Salemba Infotek Publishing. [Indonesian]

80. Zaman, A., Niwaz, A., Faize, F. A., Dahar, M. A. \& Alamgir. (2010). Analysis of Multiple Choice Items and the Effect of Items' Sequencing on Difficulty Level in the Test of Mathematics. European Journal of Social Sciences, 17(1) 61-67.

81. Zucker, S. (2003). Fundamentals of Standardized Testing: Assessment Report. Texas: Pearson Education, Inc. 
NOTES 